Article

\title{
Urban Land-Use Dynamics in the Niger Delta: The Case of Greater Port Harcourt Watershed
}

\author{
Nimi G. Dan-Jumbo ${ }^{1, * \mathbb{D}}$, Marc J. Metzger ${ }^{1}$ and Andrew P. Clark ${ }^{2} \mathbb{D}$ \\ 1 School of Geosciences, The University of Edinburgh, Edinburgh EH8 9XP, UK; marc.metzger@ed.ac.uk \\ 2 School of Environment and Life Sciences, The University of Salford, Salford M5 4WT, UK; \\ A.P.Clark@salford.ac.uk \\ * Correspondence: nimi.dan.jumbo@outlook.com or n.dan-jumbo@ulster.ac.uk; Tel.: +44-7561120814
}

Received: 8 October 2018; Accepted: 16 November 2018; Published: 20 November 2018

\begin{abstract}
Cities in developing countries are urbanising at a rapid rate, resulting in substantial pressures on environmental systems. Among the main factors that lead to flooding, controlling land-use change offers the greatest scope for the management of risk. However, traditional analysis of a "from-to" change matrix is not adequate to provide information of all the land-use changes that occur in a watershed. In this study, an in-depth analysis of land-use change enabled us to quantify the bulk of the changes accumulating from swap changes in a tropical watershed. This study assessed the historical and future land-use/land-cover (LULC) dynamics in the River State region of the Niger Delta. Land-use classification and change detection analysis was conducted using multi-source (Landsat TM, ETM, polygon map, and hard copy) data of the study area for 1986, 1995, and 2003, and projected conditions in 2060. The key findings indicate that historical urbanisation was rapid; urban expansion could increase by $80 \%$ in 2060 due to planned urban development; and $95 \%$ of the conversions to urban land occurred chiefly at the expense of agricultural land. Urban land was dominated by net changes rather than swap changes, which in the future could amplify flood risk and have other severe implications for the watershed.
\end{abstract}

Keywords: land-use/land-cover change; impact; urbanisation; change detection; post-classification; land-use dynamics

\section{Introduction}

Globally, cities are urbanising at unprecedented rates, resulting in profound and unintended impacts on landscapes and urban hydrology [1-4]. Urbanisation is defined as the concentration of people in urban settlements and the process of change in land-use occupancy, resulting from the conversion of rural lands into urban, suburban, and industrial communities [5,6]. In 2014, more than half $(54 \%)$ of the world's population lived in cities [2,7] and by 2050, the urban population is projected to rise by 2.5 billion people, with $90 \%$ of this population anticipated to be concentrated in Asia and Africa, where $60 \%$ of this population is anticipated to live in slums [2]. There is now a wide consensus that cities in Asia and Africa are more vulnerable to the effects of flooding due to increased urbanisation, climate change, poor planning, weak regulations, and poor adaptive capacity [2,8-10]. As a consequence, there is a critical need to understand the historical patterns of land-use change, the extent of future urbanisation and their resulting impacts on urban landscapes in these regions to inform flood risk management strategies.

Greater Port Harcourt (GPH) city in Nigeria is a compelling example of rapidly urbanising cities in Africa, with a delicate and dynamic wetland environment that is very sensitive to flooding [11]. Since 1965, Port Harcourt municipality has been the site of Nigeria's largest harbour and the centre of its petroleum activities $[12,13]$. From its initial development, the city's planning authority has struggled to 
cope with the physical expansion and overcrowding issues due to a continual rise in population [14,15]. Currently, their vision (developed in 2009) to expand, modernise, and transform the city into an internationally recognised destination is being implemented with a 50-year integrated urban master plan $[14,16]$. However, research has shown that both planned and unplanned developments can have significant negative effects on urban landscapes and could have severe flood risk implications [2,17-19]. Therefore, understanding the extent and nature of the land-use/land-cover (LULC) changes using multi-temporal satellite data is vital for interpreting landscape dynamics and will aid in strengthening planning policy in the region.

Empirically, LULC change results have extensive use in flood modelling [20-24]. For example, Du et al. [20] used LULC data inputs to generate scenarios for assessing the effects of urbanisation in the Qinhui River Basin in China. Elsewhere, McColl and Aggett [25] utilised LULC data for forecasting flood impacts in Kittitas County in Washington, United States (USA). In terms of hydraulic modelling, Duan et al. [26] used remotely sensed data to produce flood maps of Chiang Mai province in Northern Thailand. For hydrological purposes, land-use data are applied as spatial data for generating curve number (CN, an index for determining run-off potential), percentage of impervious surfaces (PctImp), and Manning's N (roughness coefficient), which are all dependent on the land cover properties.

Satellite remote sensing is a method that is frequently used to detect land-use changes on landscapes [27], involving the application of multi-sourced and multi-date satellite imageries to estimate the difference in the extent of land cover. Remotely sensed data can be effectively used to quantify changes in a consistent and accurate way over a range of temporal and geographical scales [27-30]. Moreover, satellite remote sensing provides the most common source of data for mapping the change patterns that can, in most cases, be readily and repeatedly obtained in a digital and georeferenced format [31]. However, a limitation with this method is that different features can be difficult to identify if they appear the same to the sensor and may lead to misclassification; for example, artificial and natural grass in green light may display the same characteristics.

In the past, researchers have applied a range of change detection methods that can broadly be grouped into pre-classification and post-classification [17,27,32-34]. Pre-classification involves the analysis of transformed images from two different dates. The methods used to perform this analysis include principal component analysis (PCA), band combination (BC), vegetation index differencing (VID), image regression, image rationing, and background subtraction techniques [31,34,35]. In contrast, the post-classification method employed in this study classifies multi-temporal images into thematic maps, and then implements a pixel-by-pixel comparison of the classified images.

The post-classification detection method offers a rational and more efficient means of estimating changes, because in addition to its traditional use for determining the extent (percentage) of change (for utilisation as an input for flood modelling), it can also be used to examine the nature of change i.e., to analyse the 'from-to' changes. However, the final accuracy of change determination depends on the quality of the classified image for each date [33]. As a result, several existing studies have provided limited insight into the processes that influence the pattern of land-use change and the component of change [36]. Beyond the extent of change and land-use conversions, this study was able to examine the other nature of change components, as well as the process of change, which could have a bearing on flooding in the watershed.

Presently, a number of studies have investigated the extent of land use change in the GPH watershed [20,22,37]. However, land-use detection studies that account for the processes that determine change through an analysis of the nature of this change are rare. In addition to accounting for the process of change, these studies neglected land persistence as a significant factor. According to Pontius et al. [36], total change in landscapes could result from two processes: swap changes (change in location) and net changes (i.e., change in quantity). This study argues that accounting for net change only limits understanding of the sum of changes that occur within a landscape. The analysis of landscape persistence, gains, and losses is informative and vital to understanding the nature of changes that occur over time. 
The concept of swap change is very important, as it gives information about the processes that determine the change. Accounting for the total change of landscapes is often overlooked in change detection studies [36]. This study addresses a gap in the existing body of knowledge relating to the study area, as it provides a more comprehensive interpretation of the sum of changes. Importantly, it explains the nature of change in the watershed that could have implications for flood risk.

In this study, supervised classification was applied in the image classification process and later used to derive the cross-tabulation matrix. The cross-tabulation matrices for 1986, 1996, and 2003 were extended to derive the gross gains, gross losses, and persistence by principal categories. Swap and net changes were derived from the extended cross-tabulation matrix.

Since land-use change resulting from the implementation of the GPH 50-year development plan can have serious implications for the watershed, the purpose of this paper is to understand the historical and future LULC dynamics in the Greater Port Harcourt watershed. The key questions are: What was the extent and nature of historical LULC changes? What will be the extent of future urban LULC changes due to implementation of the plan by 2060? What are the dominant forces and the trend of urban land-use change in the watershed? Lastly, does the application of multi-source data affect result accuracy?

\section{Study Area}

The study area under investigation is a lowland watershed made up of five major basins and 39 sub-basins spanning about $4820 \mathrm{~km}^{2}$ and is in River State, which is the southernmost part of the Niger Delta in Nigeria (Figure 1). This study area is a hydrologically sensitive coastal plain that is barely $20 \mathrm{~m}$ above sea level. It is relatively a flat terrain with a slope not greater than $3 \%$ [38], and is located between $4^{\circ} 42$ north and $4^{\circ} 47$ north latitude as well as $6^{\circ} 55$ east and $7^{\circ} 08$ east longitude in the equatorial region of the world.

Administratively, Greater Port Harcourt (GPH) city is an agglomeration of eight local communities surrounding the Port Harcourt city. GPH was comprised of Port Harcourt city, Obio-Akpo, and Okrika areas prior to the establishment of the Greater Port Harcourt Law in 1999. Currently, based on the newly implemented urban master plan, GPH city now also includes the Ikwerre, Oyigbo, Ogu/Bolo, Etche, and Eleme administrative areas [16]. Port Harcourt is one of two cities with the highest population in the Niger Delta; it has witnessed an exponential population growth with an annual growth rate of 3.0\%, resulting in population eruption from about 180,000 people in 1963 to about two million in 2016 [39]. By 2020, the population of Rivers State is projected to rise from about three million to seven million people [40].

Development controls in Nigeria date back to the colonial era with the enactment of the Township Ordinance No. 29 of 1917 as the first attempt of introducing spatial orderliness into the land-use pattern in Nigerian cities, and later the Nigeria Town and Country Planning Ordinance (No. 4 of 1946) to provide for the development and improvement of different parts of the country through planning schemes initiated by the planning authorities [41-43]. However, those regulations only reflected the social and economic needs of the colonialists at the time.

Since independence in 1960, planning authorities have increasingly used development controls with the aim of achieving the efficient and effective use of land, as well as physical improvement across the country. The Nigerian Urban and Regional Planning Law, Decree No. 88 of 1992, and a subsequent amendment, the Urban and Regional Planning (Amendment) Decree No. 18 of 1992, were later enacted [41,43]. These latter land-use regulations generally set out limits, principles, and procedures for dealing with land-use issues such as overcrowding and congestion. Despite these statutory controls, issues of overcrowding and the construction of squatter settlements persist, and levels of compliance remain low [42]. The federal, state, and local governments share responsibility for land-use planning and development control, with the Federal Planning Commission taking responsibility for national physical development plans and sub-regional plans, the Rivers State Urban and Regional Planning 
Board controlling urban and regional plans in the state, and the local planning authorities controlling the town and rural plans $[42,44]$.

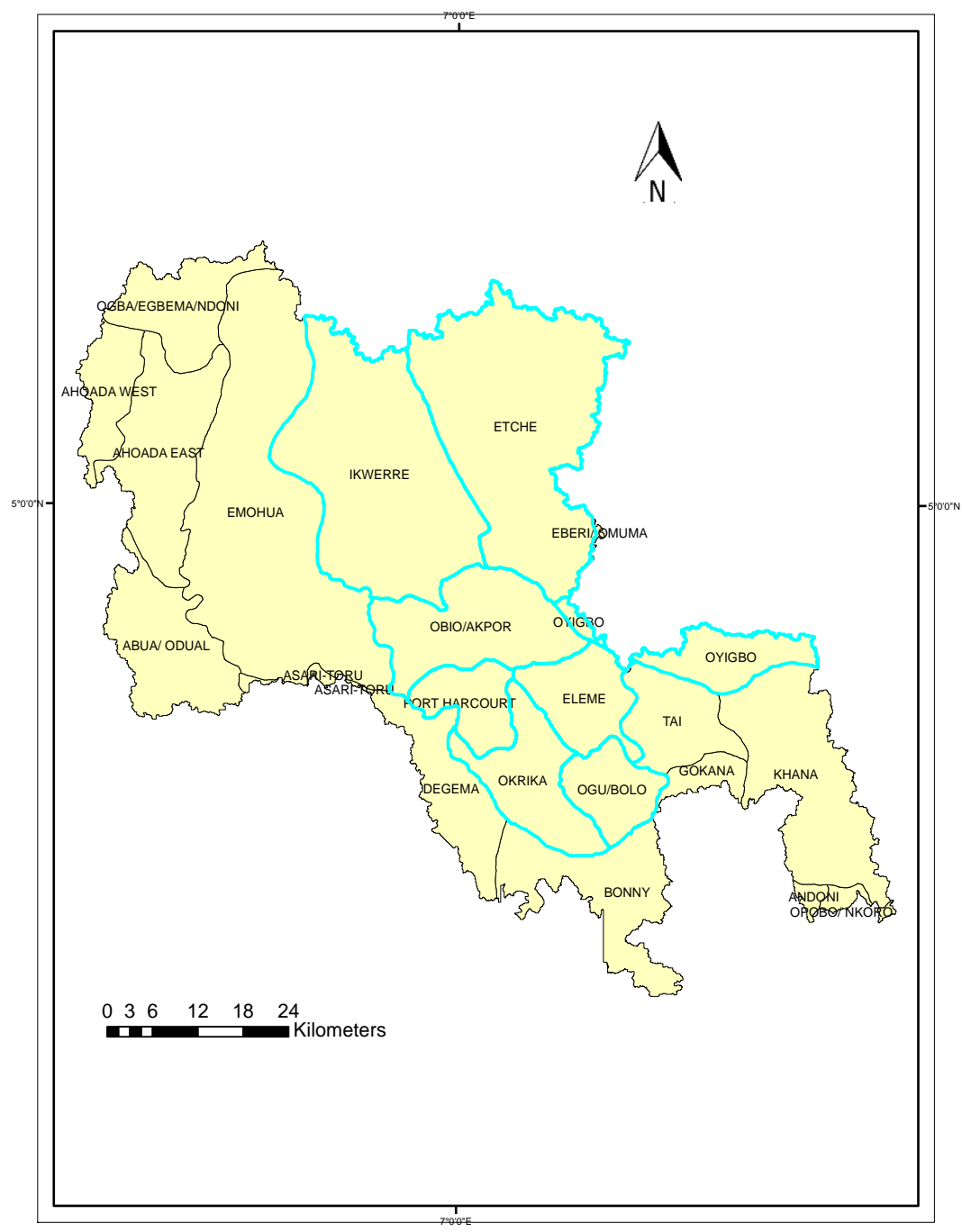

Figure 1. Map of the entire Watershed under study. Areas bordered with green lines are the administrative areas of Greater Port-Harcourt in River State, Nigeria.

\section{Materials and Methods}

This study adopted the post-classification change detection approach for analysing historical LULC changes. Four major steps were followed in analysing historical LULC changes, which were data acquisition, image enhancement, supervised classification, and change detection analysis. These steps can be grouped under the pre-processing, classification, and post-classification stages (Figure 2). The analysis of the extent of future changes was estimated by overlaying the GPH master plan (digitised vector map) on the baseline map derived from the satellite data. 


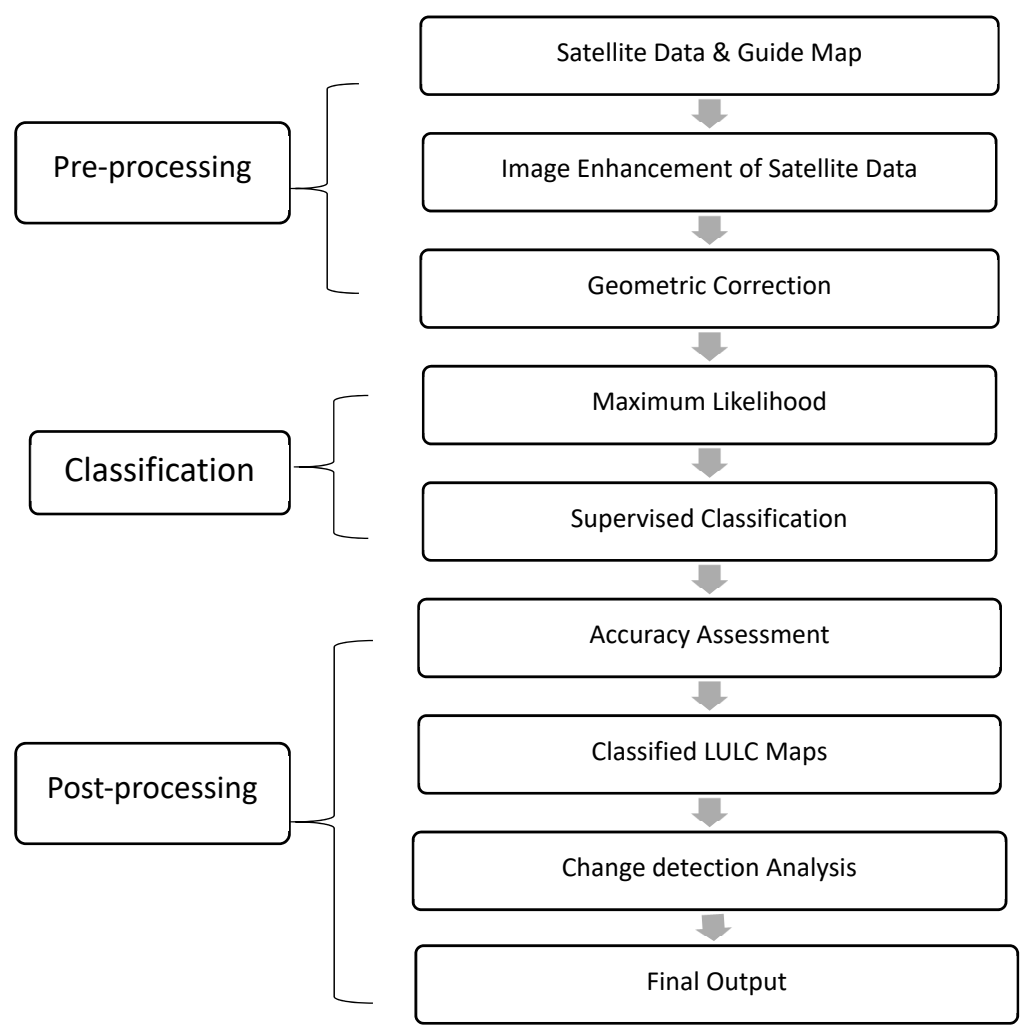

Figure 2. Flow chart of land-use classification procedure used in this study. Source: Singh and Kumar (2012).

\subsection{Data Acquisition}

For this study, two multi-temporal and multi-spectral imagery data sets and a vector map were obtained to generate digital maps for analysing historical changes between 1986-2003. The three historical data sets obtained include one Landsat Thematic Mapper (TM) imagery for the year 1986; one polygon map for the year 1995; and one Landsat Enhanced Thematic Mapper plus (ETM+) map for the year 2003. These dates were selected to benchmark approximate decadal changes of the landscape. One limitation of this approach is the use of multi-sourced data that could increase uncertainty due to the varying spatial and spectral resolutions of the data set. This problem is common and often unavoidable in studies spanning over decades. Despite the limitation, a similar approach has been successfully followed in detecting land-use changes in prior studies $[17,20,31]$.

The TM and ETM+ are Landsat satellite data (Table 1) were obtained free of charge from the United States Geological Survey Global Land Facility website (http:/ / glcf.umd.edu/data/landsat/). TM sensor data were used because it is the only freely available data covering the spatial and temporal extent of the study area. The 1995 polygon map was obtained from the Rivers State's Ministry of Land and Housing (Riv-MoLH), with this data generated using the aerial survey method by the Riv-MoLH, and then converted to a polygon map. The polygon map was also applied because it was the only available cloud-free data for the 1995 time period. High cloud cover and satellite scanner issues hindered the use of more recent maps (2007 onwards) of the area. Originally, 2009 was selected as the baseline year as it benchmarks the commencement of the GPH development, but due to the unavailability of appropriate data for that year, 2003 was adopted as the baseline year. Although this could increase the uncertainty of the result, the effect may not be significant, given that the temporal difference is less than 10 years, and because the change in urban area is the main interest of this study. Ultimately, the criterion used for data selection was that maps must have $20 \%$ or less cloud cover. 
Table 1. Metadata of satellite images used in this research. Source: United States Geological Survey.

\begin{tabular}{|c|c|c|c|c|c|c|c|}
\hline Year & Path/Row & Sensor & Satellite & Original Bands Numbers & Pixel Resolution & Spectral Range & Map Band Combination \\
\hline 1986 & $\begin{array}{l}188 / 056 \\
188 / 057 \\
189 / 056 \\
189 / 057\end{array}$ & TM & Landsat-5 & $1,2,3,4,5,7$ & $30 \mathrm{~m}$ & $0.450-2.35 \mu \mathrm{m}$ & $\begin{array}{l}\text { Red } \\
\text { Green } \\
\text { Blue }\end{array}$ \\
\hline 2003 & $\begin{array}{l}188 / 056 \\
188 / 057 \\
189 / 056 \\
189 / 057\end{array}$ & ETM+ & Landsat-7 & $1,2,3,4,5,7$ & $30 \mathrm{~m}$ & $0.450-2.35 \mu \mathrm{m}$ & $\begin{array}{c}\text { Red } \\
\text { Green } \\
\text { Blue }\end{array}$ \\
\hline
\end{tabular}

\subsection{Image Processing}

Image processing was carried out prior to change detection analysis. Images were manipulated in a geographical information system (GIS) environment in order to relate data to the true biophysical environment. A number of sub-processes were undertaken, including mosaicking, geometrical correction, map registration, atmospheric correction, and image enhancement to manipulate the selected scenes. Due to the position and scale of the maps, four map tiles were obtained and merged for each year. The maps were then spatially referenced to WGS_84_UTM_Zone_32N in the Universal Transverse Mercator (UTM) system.

Next, image enhancement was performed by adjusting the image values to highlight the distinct features for improving the visual interpretability of the maps. While the range of image enhancement techniques is broad, the composite colour generation technique was applied for enhancing images, because it makes the fullest use of the capabilities of the human eye. Natural colour band combination $(3,2,1)$, characterised by short wavelengths, was applied for image classification of the years 1986 and 2003 .

\subsection{Supervised Classification}

The image classification process involved the conversion of multi-band raster imagery into a single-band raster with categorical classes that relate to different LULC classes [45]. In this study, the supervised classification (a deterministic) method was applied. It was applied to the 1986 (TM) and $2003(\mathrm{ETM}+)$ satellite images, and involved clustering pixels into classes based on training data defined by the user [46]. Supervised classification was performed for the 1986 (TM) and 2003 (ETM+) satellite data. This method was preferred over the unsupervised classification method as it provides the advantage of understanding not just the extent of change or change magnitude, but also because it could be used to understand land-use conversions and change processes that have taken place through a pixel-by-pixel comparison using the matrix [47].

The Maximum Likelihood Classifier (MLC) method was utilised for image classification, which was achieved by generating signatures and training samples based on field knowledge and the existing map. The signature file store spectral signatures of LULC classes across the series of bands [45] and pure pixels were used as training samples. The procedure for classifying maps involved: clipping the classified and composite maps; reclassifying the existing classified (1995) map; identifying LULC classes; collecting training samples; generating signature files; executing the maximum likelihood classification tool; creating thematic maps; and reclassifying the map from six to five classes for the 1986 and 2003 maps, and from 10 to five classes for the 1995 map. Built-up areas were reclassified to the urban category; forest, thicket, and swamp forest were reclassified to the forest category; and plantation and cultivation were reclassified to the agricultural land category. High and low mangrove were reclassified to the mangrove category, while river was reclassified to the water body category.

\subsection{Post-Processing}

After classification, overall accuracy and kappa statistics were performed to validate the classification using confusion matrices. In total, 468 random points were used to compare classes in the truth and classified maps. The main steps in accuracy assessment involved: (1) random sampling, 
extraction of reference (truth) and classified map data using the 'extract value-to-point' tool in ArcMap; and (2) comparison of the reference map to the classified map using an error matrix. Data were organised using frequency and pivot tools in ArcMap, and the overall accuracy was calculated as the total predicted pixels divided by the sum of the predicted pixels (of the major diagonal). According to Enaruvbe and Ige-Olumide [48], an overall accuracy of $<50 \%$ is poor, $50-70 \%$ is moderate, while greater that $70 \%$ is considered good. Subsequently, the Kappa statistic was used to measure the magnitude of agreement between the reference and classified map [49]. Kappa is expressed as:

$$
\text { Kappa }(\mathrm{K})=\frac{\text { Observed Agreement }- \text { Expected Agreement }}{1-\text { Expected Agreement }}
$$

\subsection{LULC Change Detection and Analysis}

After classification, land-use change detection was performed to estimate the differences between two scenes. This was achieved in two ways, first by determining the extent of change (Tables 2-4), and then by determining the nature of the change (Tables 5-11). The extent or magnitude of change is used to describe the degree of expansion or reduction in the LULC size resulting from the classification [47], with negative values indicating a reduction in LULC size, and positive values indicating an increase in the size of the LULC class.

It is expressed as:

$$
\text { Percentage of change }(\mathrm{A})=\frac{F-I}{I} \times 100,
$$

where $\mathrm{A}=$ percentage of change (i.e., percentage increased or decreased); $F=$ first date (date of the first imagery analysed); and $I=$ reference date (date of the second imagery analysed)

The nature of change was calculated from a transition matrix table, which consisted of the total and inter-category conversions of LULCs from 1986 to 2003. This was used to describe the type of "from-to" changes, transitions, and conversions that have occurred between the two dates $[47,50]$. The rationale for this analysis was to interpret the prominent transitions in a particular category from one year to the next.

Cross-tabulation was performed in the GIS environment. In the table, rows display the categories in Time 1, whereas the columns represent the categories in Time 2. Row totals at the right signify the proportion of the landscape by category in Time 1, and the column totals at the bottom represent the proportion of landscape by category in Time 2. As a first step, the off-diagonal entries were analysed, followed by the column and row total, and subsequently followed by the persistence, gross gains, and gross losses. This matrix was used to derive the total and inter-category gross gains, gross losses, and persistence, along with the absolute net change for the entire landscape and classes. Furthermore, as Pontius et al. [36] emphasised, other measures such as swap changes in the landscape as well as loss-to-persistence and gain-to-persistence ratios can be determined. These measures help define the processes that determine the transitions with the advantage of allowing determination of both the landscape and inter-categorical transitions.

Gross loss was derived by deducting persistence (diagonal entries) from the row total, and gross gain was calculated by deducting persistence from the column total. Total change was derived by summing the gross loss and gross gain, while absolute net change was calculated by subtracting the gross loss from the gross gain. By deducting the absolute net change from the total change, the swap change was derived. The loss-to-persistence ratio and the gain-to-persistence ratio can be computed using the approach in Pontius et al. [36].

\subsection{Procedure for Estimating Changes to Future Urban Area}

With the availability of the GPH Master Plan, the estimation of future changes in the urban area was performed using ArcMap 10.1, assuming that urban expansion would result mainly from the implementation of the master plan. Again, the study assumed that the conditions within the map area 
would change due to master plan implementation, while the conditions of other LULC classes outside the GPH LULC map would largely stay the same.

First, the master plan was digitized and overlaid on the 2003 baseline map. The digitisation process was done, first by georeferencing the analogue maps (master plan) to an appropriate projected coordinate system, i.e., WGS_84_UTM_zone_32N, and later by digitising the LULC classes. The main urban classes that were reclassified to urban area from the master plan include built-up area, university premises, commercial light industrial, industrial, cemetery, a dumpsite, an Airforce base, and the international airport. Open spaces, active open spaces, and golf courses were also reclassified to agricultural land. Next, LULC classes from the GPH Master Plan were reclassified into urban, forest, agriculture, mangrove, and water based on percentage sealing and tree coverage. Riverine areas were reclassified to mangrove, while water body was reclassified to waterbody.

\section{Results}

\subsection{Accuracy Assessment}

Figures 3-5 display classified maps for 1986, 1995, and 2003, respectively. Compared to the 1995 map, the overall accuracy of the 1986 and 2003 classified maps were $75.9 \%$ and $70.51 \%$ respectively (see Tables 5-7). Kappa statistics calculated for the 1986 and 2003 classified maps were 0.54 and 0.50, respectively, which clearly indicate that the overall accuracy of both maps was reasonable, because they were above $70 \%$, and the kappa statistics for both maps represent a moderate rating.

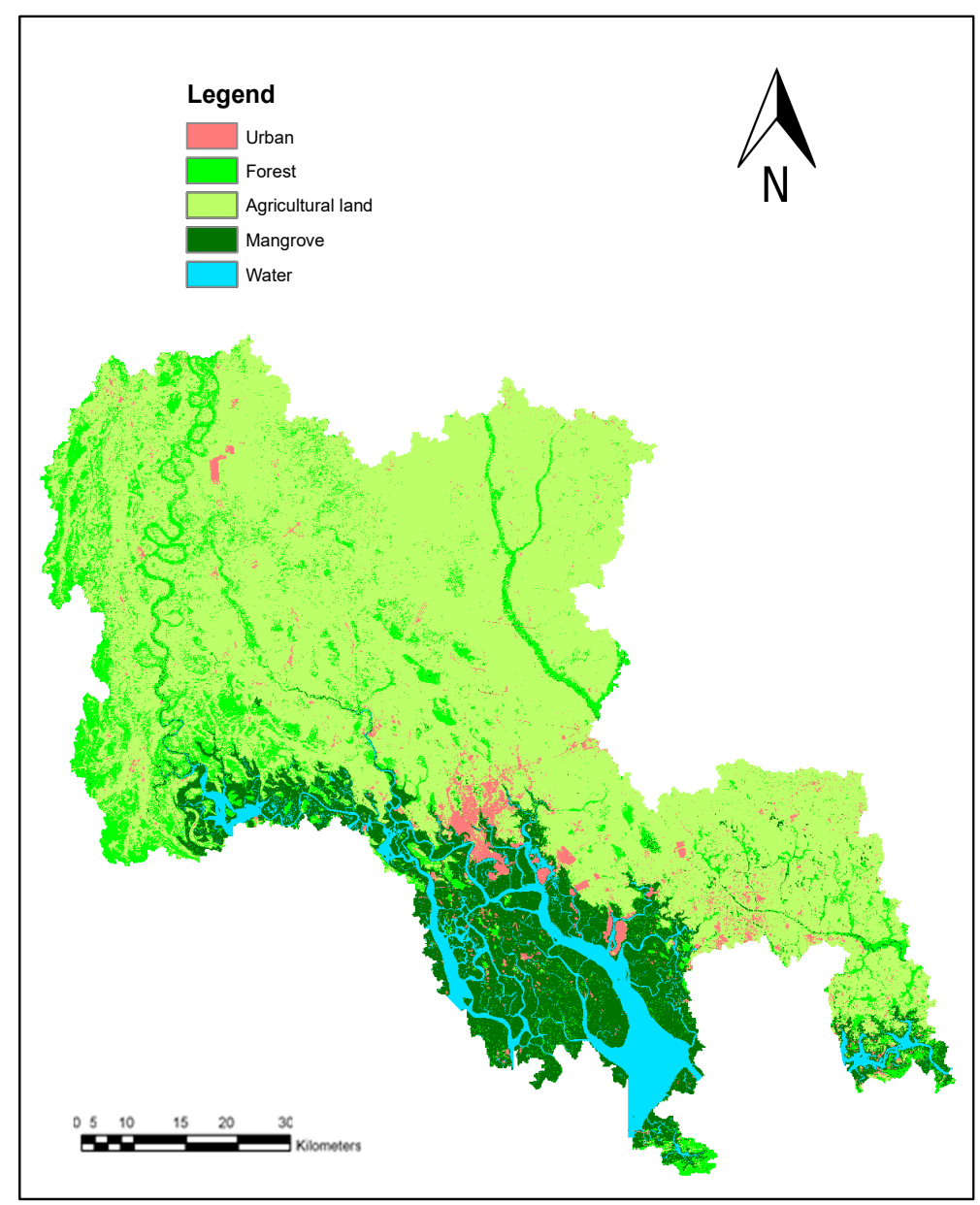

Figure 3. Map showing the classified land-use/land-cover (LULC) map of Greater Port Harcourt watershed for 1986. LULC classes include Urban Area, Forest, Agricultural Land, Mangrove, and Water. 


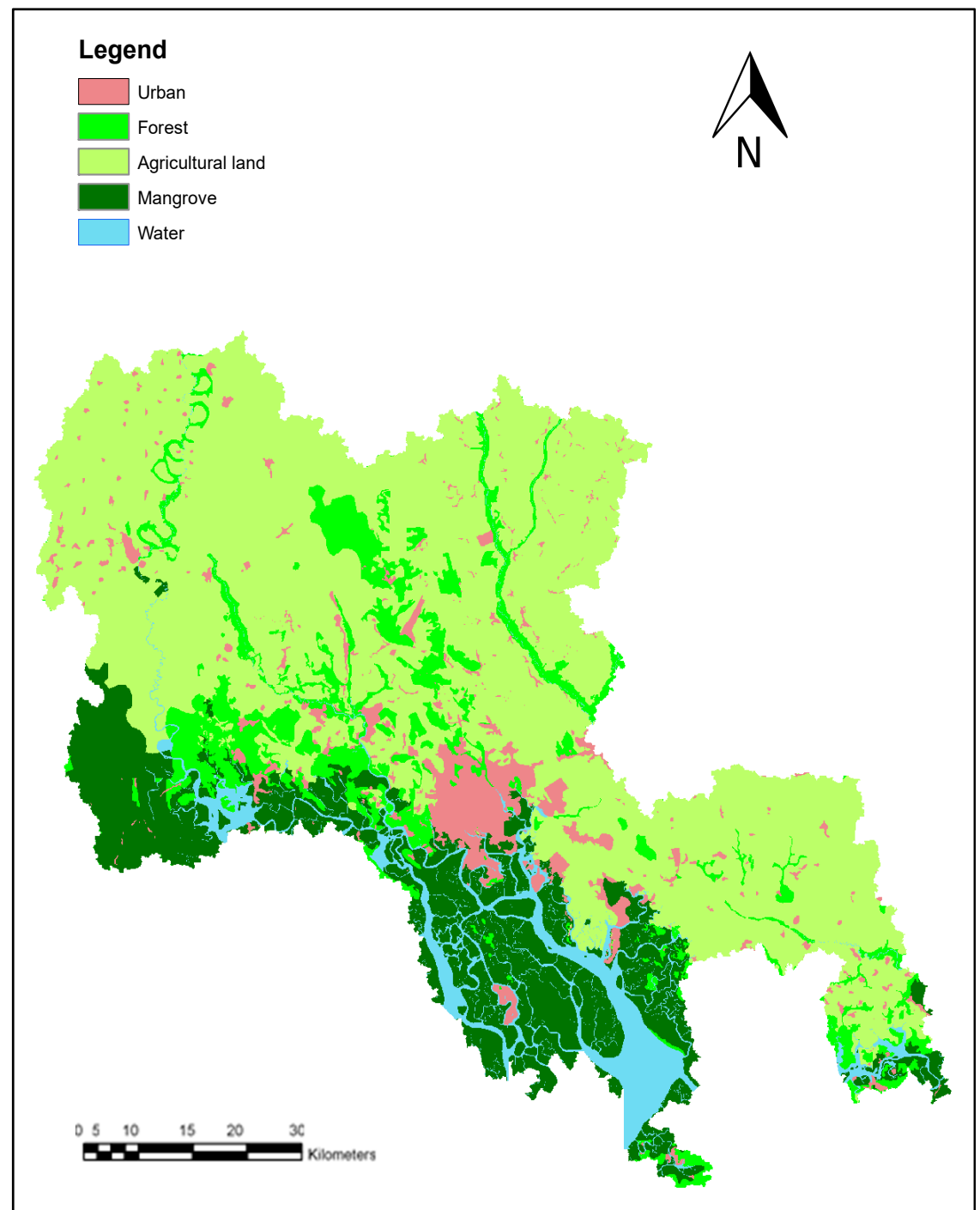

Figure 4. Map showing the reclassified LULC map of Greater Port Harcourt watershed for 1995. LULC classes include Urban Area, Forest, Agricultural Land, Mangrove, and Water. 


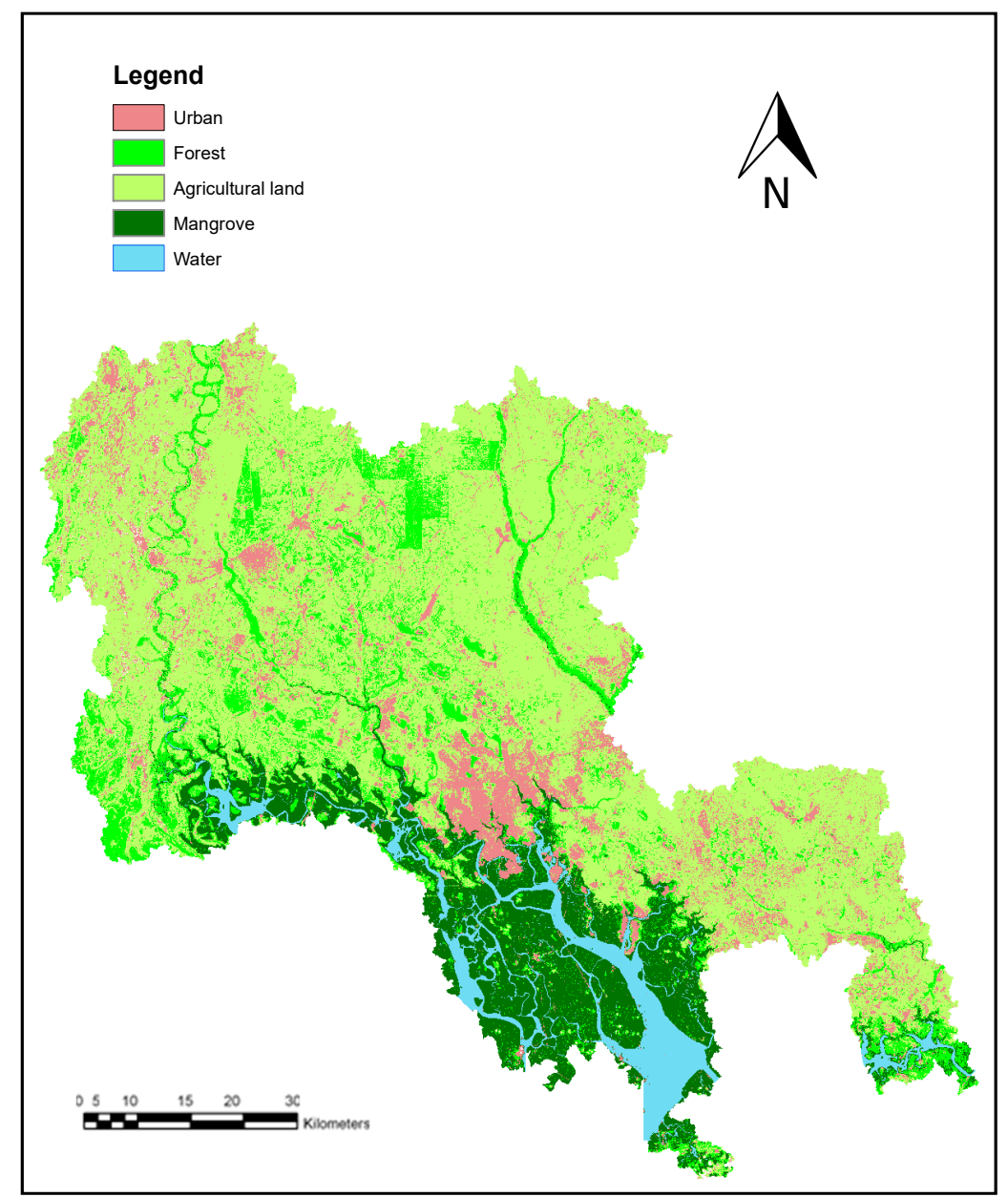

Figure 5. Map showing the classified LULC map of Greater Port Harcourt watershed for 2003. LULC classes include Urban Area, Forest, Agricultural Land, Mangrove, and Water.

\subsection{Extent of Historical Urban LULC Change}

Row 1 in Table 2 shows the proportion and area of historical urban land use/land cover in the watershed between 1986-2003. The results indicate that significant urban expansion occurred between 1986-2003. The trend line in Figure 6 and historical maps in Figures 3-5 further demonstrate that the historical change was progressive, while the bar chart indicates that the LULC changes between approximate successive decades were significant. For example, the urban LULC category increased in proportion from about $2.7 \%$ in 1986 to about $5.8 \%$ in 1995, and finally to around $11 \%$ in 2003 (see Tables 2-4). Table 2 and Figure 6 indicate that the landscape experienced a drastic change of about $309 \%$ between 1986-2003, because urban area expanded from about $134.5 \mathrm{~km}^{2}$ in 1986 to about $550 \mathrm{~km}^{2}$ in 2003. This means that the urban area expanded at a rate of about $24 \mathrm{~km}^{2} /$ annum within the entire historical period studied. Although the percentage change in the later period (1995-2003) was slightly lower than that in the earlier period (1986-1995), the results demonstrate that the expansion in the first and second time period were similar, showing that significant urban growth occurred in the past between 1986-2003, and that the growth was progressive. 
Table 2. Changes in urban area and other LULC categories between 1986-2003. Changes in this table indicate that there was a significant increase in urban area.

\begin{tabular}{ccccccc}
\hline \multirow{2}{*}{ Class Name } & \multicolumn{2}{c}{$\mathbf{1 9 8 6}$} & \multicolumn{2}{c}{$\mathbf{2 0 0 3}$} & \multicolumn{2}{c}{ Change } \\
\cline { 2 - 7 } & Percentage & Square Kilometers & Percentage & Square Kilometers & Square Kilometers & Percentage \\
\hline Urban & 2.8 & 134.5 & 11.4 & 550.0 & 415.5 & 308.9 \\
Forest & 12.5 & 600.2 & 10.9 & 526.5 & -73.7 & -12.3 \\
Agric. Land & 65.9 & 3174.6 & 59.9 & 2885.5 & -289.2 & -9.1 \\
Mangrove & 13.2 & 636.4 & 12.9 & 622.3 & -14.1 & -2.2 \\
Water & 5.7 & 275.3 & 4.9 & 236.7 & -38.6 & -14.0 \\
Total & & 4821.0 & & 4821.0 & & \\
\hline
\end{tabular}

Table 3. Changes in urban area and other LULC categories between 1986-1995. Changes in this table indicate that urban area experienced a significant increase.

\begin{tabular}{ccccccc}
\hline \multirow{2}{*}{ Class Name } & \multicolumn{2}{c}{1986} & \multicolumn{2}{c}{$\mathbf{1 9 9 5}$} & \multicolumn{2}{c}{ Change } \\
\cline { 2 - 7 } & Percentage & Square Kilometers & Percentage & Square Kilometers & Square Kilometers & Percentage \\
\hline Urban & 2.8 & 134.5 & 5.8 & 277.3 & 142.8 & 106.1 \\
Forest & 12.5 & 600.2 & 11.1 & 534.6 & -65.6 & -10.9 \\
Agric. Land & 65.9 & 3174.6 & 60.1 & 2896.2 & -278.4 & -8.8 \\
Mangrove & 13.2 & 636.4 & 16.9 & 812.8 & 176.5 & 27.7 \\
Water & 5.7 & 275.3 & 6.2 & 300.1 & 24.8 & 9.0 \\
Total & & 4821.0 & & 4821.0 & & \\
\hline
\end{tabular}

Table 4. Changes in urban area and other LULC categories between 1995-2003. Changes in this table indicate that urban area experienced a significant increase.

\begin{tabular}{ccccccc}
\hline \multirow{2}{*}{ Class Name } & \multicolumn{2}{c}{1995} & \multicolumn{2}{c}{$\mathbf{2 0 0 3}$} & \multicolumn{2}{c}{ Change } \\
\cline { 2 - 7 } & Percentage & Square Kilometers & Percentage & Square Kilometers & Square Kilometers & Percentage \\
\hline Urban & 5.8 & 277.3 & 11.4 & 550.0 & 272.7 & 98.4 \\
Forest & 11.1 & 534.6 & 10.9 & 526.5 & -8.1 & -1.5 \\
Agric. Land & 60.1 & 2896.2 & 59.4 & 2862.5 & -33.7 & -1.2 \\
Mangrove & 16.9 & 812.8 & 12.9 & 622.3 & -190.5 & -23.4 \\
Water & 6.2 & 300.1 & 4.9 & 236.7 & -63.4 & -21.1 \\
Total & & 4821.0 & & 4821.0 & & \\
\hline
\end{tabular}

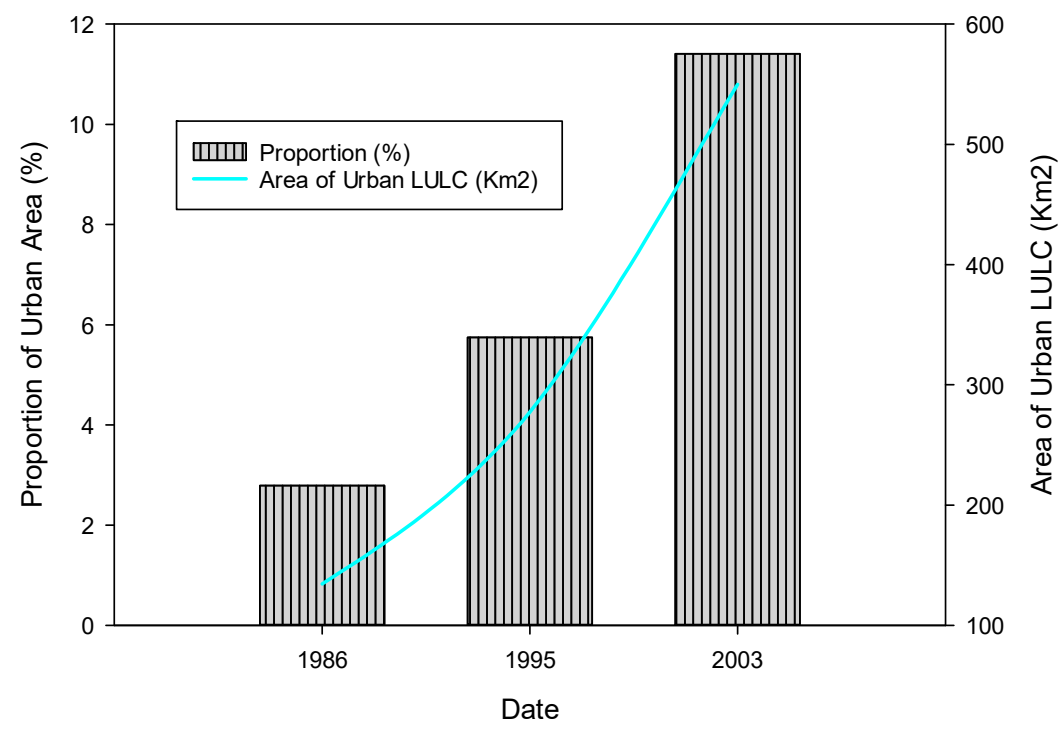

Figure 6. Proportion and trend of changes in urban area between 1986-2003. The bar chart presents the proportion of urban area for the respective dates, while the line graph shows the trend and change in urban land-use area.

\subsection{Estimated Extent of Urban LULC Change by 2060}

Table 5 presents the results of the projected percentage change in urban area by 2060 resulting from implementation of the master plan. Based on the map in Figure 7 and chart in Figure 8, this study 
projects that the urban LULC category would expand significantly by about $80 \%$ by 2060 . Meanwhile, the stacked bar chart in Figure 9 indicates a progressive growth in the proportion of urban area, which is expected to rise from about $11 \%$ in 2003 to about $20 \%$ by 2060 , meaning a double increase of the urban area. The bar chart displays a significant rise in the urban land category from about $550 \mathrm{~km}^{2}$ in 2003 to about $988 \mathrm{~km}^{2}$ in 2060, which represents respectively an $80 \%$ and $600 \%$ growth from the 2003 and 1986 calculated urban land cover.

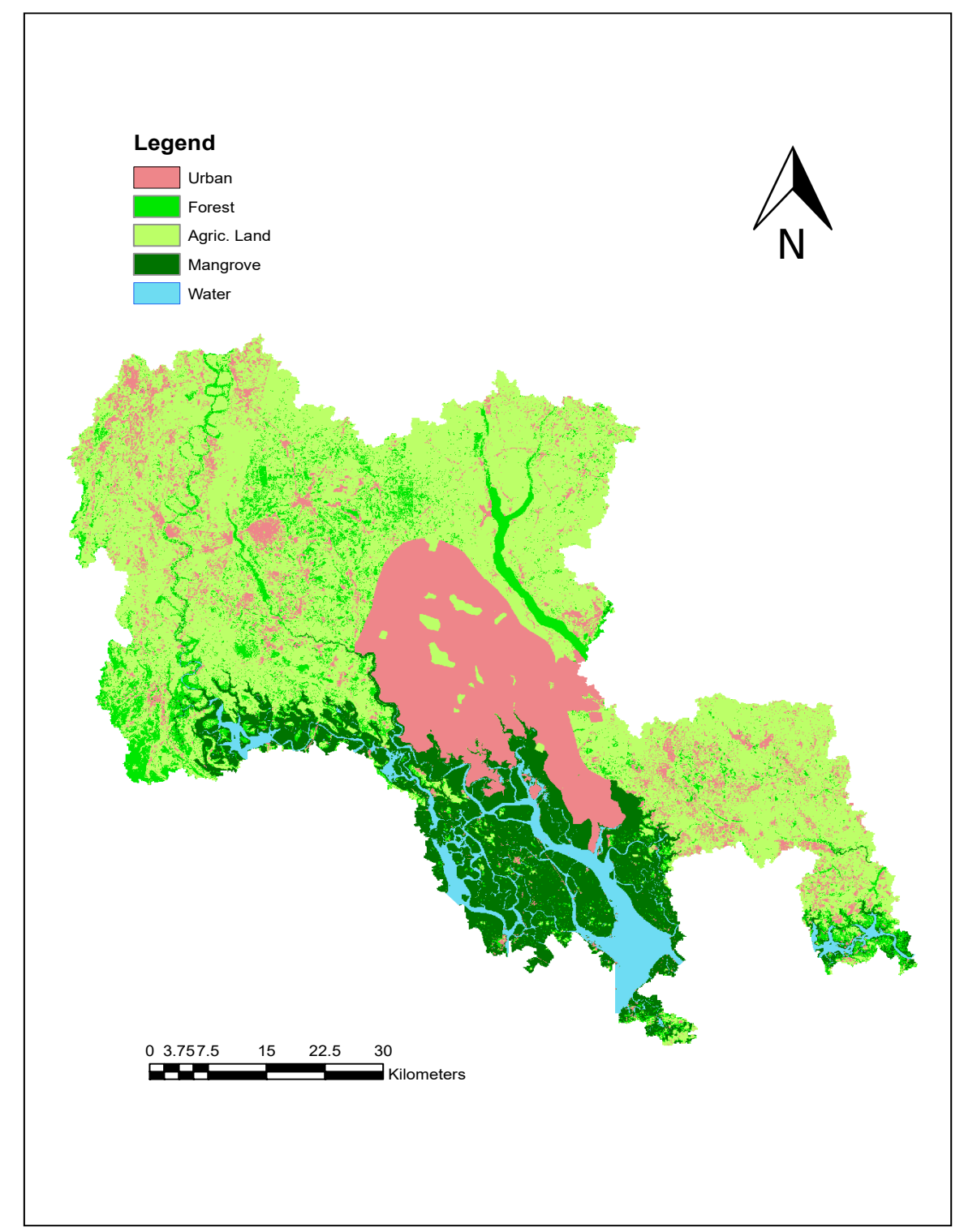

Figure 7. Map showing the extent of urban area on the 2003 base map. The superimposed 2060 data are based on the GPH Urban Master Plan. LULC classes include Urban Area, Forest, Agricultural Land, Mangrove, and Water. The 2060 Urban Master Plan was sourced from the Greater Port Harcourt Development Authority (GPHDA, 2010). 


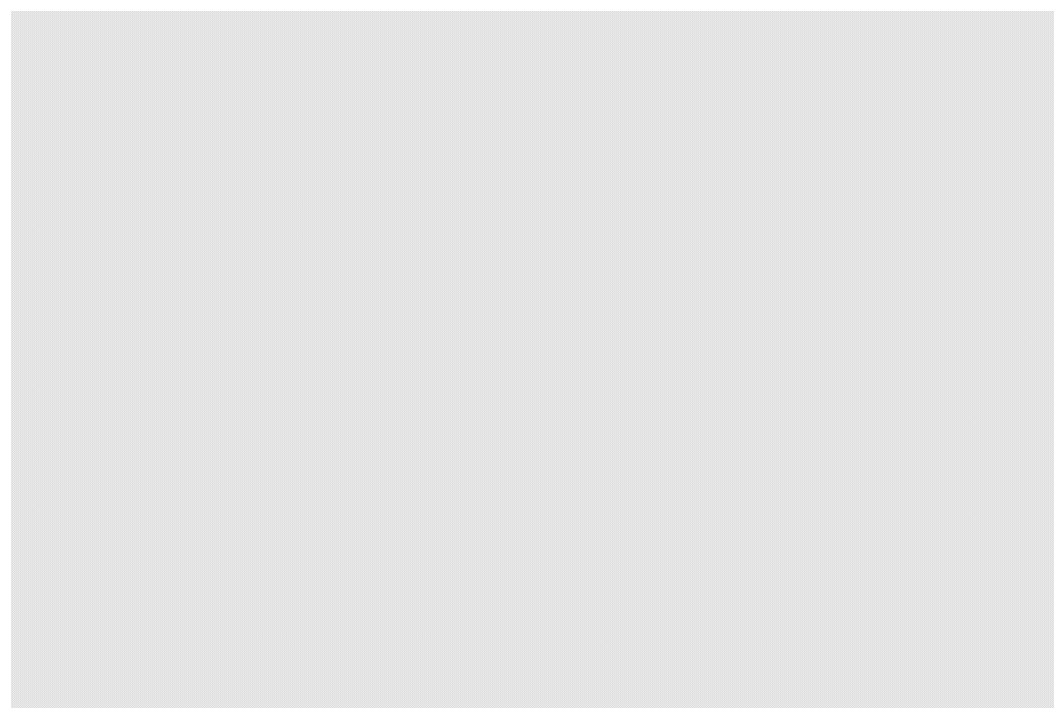

Figure 8. Proportion and trend of urban area changes between 1986-2060. The bar chart shows the proportion of urban area for the respective dates. The line graph shows the trend and changes in urban land-use area.

\subsection{Comparison of the Extent of Urban and Non-Urban Change Categories}

Figure 9 also shows the proportion of urban and non-urban LULC categories, and demonstrates that the proportion (in percentage) of urban area increased progressively, while the proportion of other LULC categories decreased at some point in time or remained the same.

Notably, the proportion of agricultural land gradually declined from $65.9 \%$ in 1986 to $60.08 \%$ in 1995 to $59.9 \%$ in 2003. Similarly, the proportion of afforested area declined slightly, from about $12.5 \%$ in 1986 to about 11.1\% in 1995, and about 10.9\% in 2003. Apart from the 1995 map, mangrove and water largely remained the same. Changes in mangrove land cover in the map could have resulted due to error from overclassification of the mangrove class in the 1995 map obtained from the River State Ministry of Housing. Nonetheless, graphically, the classified raster maps demonstrate that rapid urban expansion occurred in the past with little or no expansion of other non-urban categories.

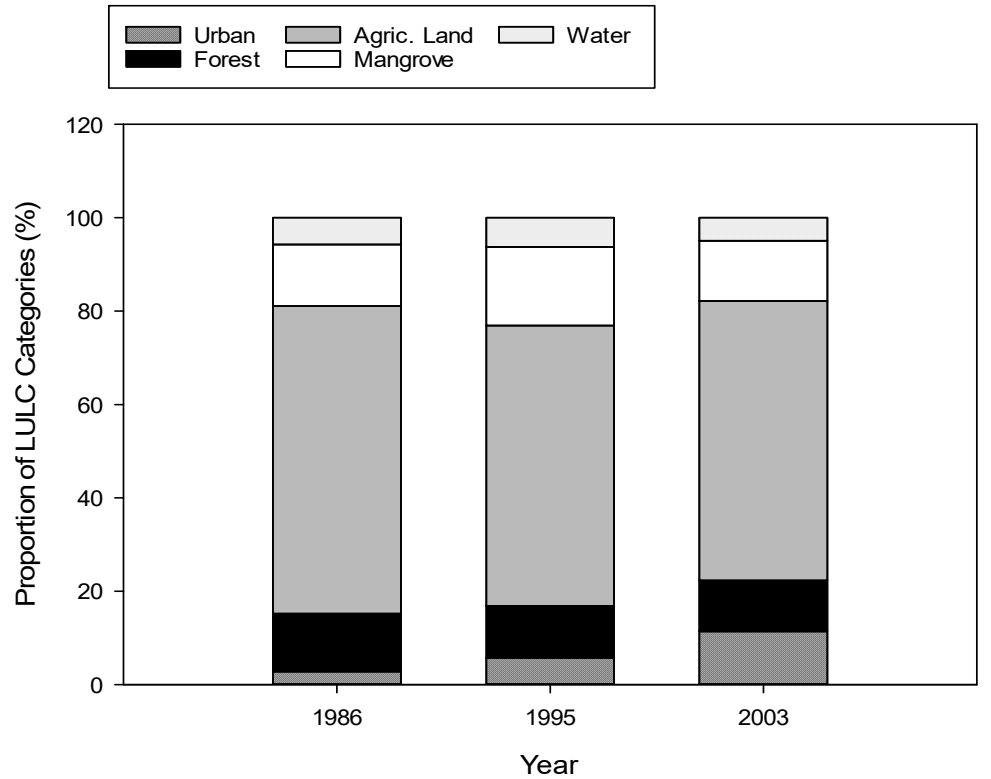

Figure 9. Stacked bar chart used for comparing the proportions of all the LULC categories. Generally, the bar chat shows that the study area experienced an incremental growth in urban area and a decline in agricultural land. 


\subsection{Analysis of the Nature of Historical Changes.}

\subsubsection{Urban Transitions}

Based on the land-use conversion results (Tables 5-7), it was found that urban area increased significantly mainly at the expense of agricultural land. Results show that the conversion of all the other LULC categories to urban area caused a total of $549 \mathrm{~km}^{2}$ in urban area between 1986-2003. The most prominent transition involves the conversion of agricultural land (about $422 \mathrm{~km}^{2}$ ) to urban land. That means that about $93.3 \%$ of all conversions to urban land resulted from development on agricultural land. In contrast, the conversion of other LULC classes to urban areas were very low, such that the transition from mangrove, forest, and water to urban area were only about $15.3 \mathrm{~km}^{2}, 13.3 \mathrm{~km}^{2}$, and $1.9 \mathrm{~km}^{2}$ respectively.

Table 5. Land-cover transition matrix for the Greater Port Harcourt watershed area, 1986 to 2003.

\begin{tabular}{cccccccc}
\hline LULC Category & Urban & Forest & Agric. Land & Mangrove & Water & 1986 Total & 1986 Gross Loss \\
\hline Urban & 97.2 & 5.1 & 27.3 & 4.8 & 0.1 & 134.5 & 37.3 \\
Forest & 13.3 & 242.4 & 321.0 & 23.3 & 0.3 & 600.2 & 357.8 \\
Agric. Land & 422.3 & 229.5 & 2520.3 & 2.6 & 0.0 & 3174.6 & 654.4 \\
Mangrove & 15.3 & 49.4 & 16.7 & 550.8 & 4.3 & 636.4 & 85.6 \\
Water & 1.9 & 0.2 & 0.3 & 40.9 & 232.0 & 275.3 & 43.3 \\
2003 Total & 550.0 & 526.5 & 2885.5 & 622.3 & 236.7 & 4821.0 & \\
2003 Gross Gain & 452.8 & 284.2 & 365.2 & 71.6 & 4.7 & & \\
\hline
\end{tabular}

Table 6. Land-cover transition matrix of Greater Port Harcourt watershed area, 1986 to 1995.

\begin{tabular}{cccccccc}
\hline LULC Category & Urban & Forest & Agric. Land & Mangrove & Water & $\begin{array}{c}\mathbf{1 9 8 6} \\
\text { Total }\end{array}$ & $\begin{array}{c}\mathbf{1 9 8 6} \\
\text { Gross Loss }\end{array}$ \\
\hline Urban & 71.1 & 4.0 & 41.3 & 15.1 & 3.1 & 134.5 & 63.4 \\
Forest & 6.7 & 189.7 & 258.6 & 135.2 & 10.1 & 600.2 & 410.6 \\
Agric. Land & 181.5 & 300.4 & 2552.7 & 134.1 & 5.9 & 3174.6 & 621.9 \\
Mangrove & 14.4 & 37.8 & 41.2 & 481.5 & 60.1 & 635.0 & 153.5 \\
Water & 3.5 & 2.7 & 2.5 & 47.0 & 220.9 & 276.7 & 55.7 \\
1995 Total & 277.3 & 534.6 & 2896.2 & 812.8 & 300.1 & 4821.0 & \\
1995 Gross Gain & 206.2 & 344.9 & 343.5 & 331.4 & 79.2 & & \\
\hline
\end{tabular}

Table 7. Land-cover transition matrix of Greater Port Harcourt watershed area, 1995 to 2003.

\begin{tabular}{cccccccc}
\hline LULC Category & Urban & Forest & Agric. Land & Mangrove & Water & 1995 Total & 1995 Gross Loss \\
\hline Urban & 163.0 & 8.3 & 91.8 & 12.1 & 2.0 & 277.3 & 114.3 \\
Forest & 26.9 & 151.7 & 325.1 & 29.3 & 1.6 & 534.6 & 382.9 \\
Agric. Land & 326.2 & 226.1 & 2317.5 & 24.8 & 1.6 & 2896.2 & 578.7 \\
Mangrove & 28.4 & 129.5 & 145.0 & 481.2 & 28.9 & 812.8 & 331.7 \\
Water & 5.6 & 11.0 & 6.1 & 74.9 & 202.6 & 300.1 & 97.5 \\
2003 Total & 550.0 & 526.5 & 2885.5 & 622.3 & 236.7 & 4821.0 & \\
Gross Gain & 387.0 & 374.8 & 568.0 & 141.2 & 34.1 & & \\
\hline
\end{tabular}

\subsubsection{Non-Urban Transitions}

Table 8 reveals that the prominent non-urban shifts between 1986-2003 were both from forest to agricultural land (about $321 \mathrm{~km}^{2}$ ) and from agricultural land to forest (about $229.5 \mathrm{~km}^{2}$ ), resulting in a net change from forest to agricultural land of $92.5 \mathrm{~km}^{2}$ with the conversion of forest to agricultural land accelerating between 1995-2003. In addition, the conversion of $135 \mathrm{~km}^{2}$ of forest to mangrove was another notable shift between 1995-2003. Generally, non-urban transitions were more significant in the latter period. 


\subsection{Analysis of Landscape Persistence and Components of Change}

As shown in Table 8, all of the LULCs (i.e., the landscape) made a total gross gain of $1178.4 \mathrm{~km}^{2}$, which is about $25 \%$ of the watershed. A gross gain of one category is accompanied by a gross loss of another category, which means the total gross gain is equal to the total gross loss in a landscape. About $75 \%$ of the landscape persisted to change. In other words, about only $25 \%$ of the watershed transitioned from one LULC category in the entire historical period of 1986-2003. Importantly, the landscape experienced a total change of $48.8 \%$ and a total absolute net of $17 \%$, while $31 \%$ of the entire watershed experienced a swap change. The urban area (with the highest intensity) had the greatest gain of about $452.8 \mathrm{~km}^{2}$ between 1986-2003, followed by a gain in agricultural land of about $365.2 \mathrm{~km}^{2}$ (Table 8). At the same time, agricultural land experienced the highest gross loss of about $654.4 \mathrm{~km}^{2}$ by a large margin, followed by mangrove (about $257.8 \mathrm{~km}^{2}$ ). In summary, the entire landscape experienced more persistence than transition and more swap change than net change.

\subsection{Inter-Category Net and Swap Change and Gain-to-Persistence Ratio}

The results in Table 8 show that although agricultural land experienced the bulk of the total change, which was characterised by swap change rather than net change, in contrast, the bulk of the urban land changes was a net change. Agricultural land and forest lands experienced more swap changes between 1986-2003 (Table 8). This swap change was significant between 1986-1995 (Table 9), however it accelerated between 1995-2003 (Table 10), while urban land and water experienced only minor swap changes between 1986-2003 (Table 8). Moreover, Table 11 illustrates that the gain-to-persistence ratio is greater than one $(>1)$ for the urban and forest categories, suggesting that urban and forest land had a higher tendency to expand than persist between 1986-2003. Urban land experienced the most prominent gain-to-persistence ratio (of about 4.7), demonstrating that the urban area was more prone to expanding than persisting when compared to other categories. 
Table 8. Ranking of gross gains, gross losses, persistence, total change, and swap change of LULC categories between 1986-2003.

\begin{tabular}{|c|c|c|c|c|c|c|c|c|c|c|c|c|}
\hline & \multicolumn{2}{|c|}{ Gross Gain } & \multicolumn{2}{|c|}{ Gross Loss } & \multicolumn{2}{|c|}{ Persistence } & \multicolumn{2}{|c|}{ Total Change } & \multicolumn{2}{|c|}{ Absolute Net Change } & \multicolumn{2}{|c|}{ Swap Change } \\
\hline \multirow{6}{*}{ 1986-2003 } & Urban & 452.8 & Agric. Land & 654.4 & Agric. Land & 2520.3 & Agric. Land & 1019.6 & Urban & 415.5 & Agric. Land & 730.4 \\
\hline & Agric. Land & 365.2 & Forest & 357.8 & Mangrove & 550.8 & Forest & 642.0 & Agric. Land & 289.2 & Forest & 568.3 \\
\hline & Forest & 284.2 & Mangrove & 85.6 & Forest & 242.4 & Urban & 490.1 & Forest & 73.7 & Mangrove & 143.1 \\
\hline & Mangrove & 71.6 & Water & 43.3 & Water & 232.0 & Mangrove & 157.2 & Water & 38.6 & Urban & 74.7 \\
\hline & Water & 4.7 & Urban & 37.3 & Urban & 97.2 & Water & 48.0 & Mangrove & 14.1 & Water & 9.4 \\
\hline & Total & 1178.4 & Total & 1178.4 & Total & 3642.6 & Total & 2356.8 & Total & 830.9 & Total & 1525.9 \\
\hline
\end{tabular}

Table 9. Ranking of gross gains, gross losses, persistence, total change, and swap change of LULC categories between 1986-1995.

\begin{tabular}{|c|c|c|c|c|c|c|c|c|c|c|c|c|}
\hline & \multicolumn{2}{|c|}{ Gross Gain } & \multicolumn{2}{|c|}{ Gross Loss } & \multicolumn{2}{|c|}{ Persistence } & \multicolumn{2}{|c|}{ Total Change } & \multicolumn{2}{|c|}{ Absolute Net Change } & \multicolumn{2}{|c|}{ Swap Change } \\
\hline \multirow{6}{*}{ 1986-1995 } & Forest & 344.9 & Agric. Land & 621.9 & Agric. Land & 2552.7 & Agric. Land & 965.4 & Agric. Land & 278.4 & Forest & 689.9 \\
\hline & Agric. Land & 343.5 & Forest & 410.6 & Mangrove & 481.5 & Forest & 755.5 & Mangrove & 177.8 & Agric. Land & 687.0 \\
\hline & Mangrove & 331.4 & Mangrove & 153.5 & Water & 220.9 & Mangrove & 484.9 & Urban & 142.8 & Mangrove & 307.0 \\
\hline & Urban & 206.2 & Urban & 63.4 & Forest & 189.7 & Urban & 269.6 & Forest & 65.6 & Urban & 126.8 \\
\hline & Water & 79.2 & Water & 55.7 & Urban & 71.1 & Water & 134.9 & Water & 23.5 & Water & 111.4 \\
\hline & Total & 1305.1 & Total & 1305.1 & Total & 3515.9 & Total & 2610.3 & Total & 688.1 & Total & 1922.2 \\
\hline
\end{tabular}

Table 10. Ranking of gross gains, gross losses, persistence, total change, and swap change of LULC categories between 1995-2003.

\begin{tabular}{|c|c|c|c|c|c|c|c|c|c|c|c|c|}
\hline \multicolumn{3}{|c|}{ Gross Gain } & \multicolumn{2}{|c|}{ Gross Loss } & \multicolumn{2}{|c|}{ Persistence } & \multicolumn{2}{|c|}{ Total Change } & \multicolumn{2}{|c|}{ Net Change } & \multicolumn{2}{|c|}{ Swap Change } \\
\hline \multirow{6}{*}{ 1995-2003 } & Agric. Land & 568.0 & Agric. Land & 578.7 & Agric. Land & 2317.5 & Agric. Land & 1146.7 & Urban & 272.7 & Agric. Land & 1135.9 \\
\hline & Urban & 387.0 & Forest & 382.9 & Mangrove & 481.2 & Forest & 757.7 & Mangrove & 190.5 & Forest & 749.7 \\
\hline & Forest & 374.8 & Mangrove & 331.7 & Water & 202.6 & Urban & 501.3 & Water & 63.4 & Mangrove & 282.3 \\
\hline & Mangrove & 141.2 & Urban & 114.3 & Urban & 163.0 & Mangrove & 472.8 & Agric. Land & 10.7 & Urban & 228.6 \\
\hline & Water & 34.1 & Water & 97.5 & Forest & 151.7 & Water & 131.6 & Forest & 8.1 & Water & 68.2 \\
\hline & Total & 1505.0 & Total & 1505.0 & Total & 3315.9 & Total & 3010.1 & Total & 545.4 & Total & 2464.7 \\
\hline
\end{tabular}


Table 11. Ratios of loss-to-persistence and gain-to-persistence for LULC conversions between 1986-2003.

\begin{tabular}{cccc}
\hline Time Period & LULC Category & Gain-to-Persistence Ratio & Loss-to-Persistence Ratio \\
\hline \multirow{4}{*}{$1986-2003$} & Urban & 4.7 & 0.4 \\
& Forest & 1.2 & 1.5 \\
& Agric. Land & 0.1 & 0.3 \\
& Mangrove & 0.1 & 0.2 \\
& Water & 0.0 & 0.2 \\
\hline \multirow{3}{*}{$1986-1995$} & Urban & 2.9 & 0.9 \\
& Forest & 1.8 & 2.2 \\
& Agric. Land & 0.1 & 0.2 \\
& Mangrove & 0.7 & 0.3 \\
& Water & 0.4 & 0.3 \\
\hline \multirow{2}{*}{$1995-2003$} & Urban & 2.4 & 0.7 \\
& Forest & 2.5 & 2.5 \\
& Agric. Land & 0.3 & 0.3 \\
& Mangrove & 0.3 & 0.7 \\
\hline
\end{tabular}

\section{Discussion}

\subsection{What Was the Extent of Historical LULC Changes}

Based on the change detection analysis, this study reveals that the urban land cover experienced significant growth in extent of over 300\% between 1986-2003, increasing from $135 \mathrm{~km}^{2}$ to around $550 \mathrm{~km}^{2}$, signifying that urban area quadrupled in extent. In a recent study of the local area by Mmom and Fred-Nwagwu [37], the urban area increased by $86 \%$ between 1986-2007, while in another [48], it was reported that only $10 \%$ change occurred. One explanation for this disparity is differences in the scope (area) of the landscape studied in each study with the area covered by the previous studies situated at a municipal (smaller) scale ranging between $400-570 \mathrm{~km}^{2}$, while the spatial extent covered by this study was at a regional scale, covering the entire watershed of about $4800 \mathrm{~km}^{2}$. In summary, this study found that the urban area quadrupled in extent, but an important lesson is that the scale of the urban landscape that is studied can have an impact on the observed extent of change.

Compared to urban expansion documented elsewhere, changes in the urban extent measured as percentage change was found to be very significant $(>100 \%)$ in this study, and other similar studies have also reported a dramatic change in urban land cover within the same time period. For example, $\mathrm{Al}$ Kuwari and Kaiser [31] discovered that urban expansion in the desert region of the western Nile Delta was very significant (4935\%) i.e., from $23 \mathrm{~km}^{2}$ in 1984 to $1158 \mathrm{~km}^{2}$ in 2005 . Another study by Shalaby and Tateishi [51] established that urban area expanded significantly by $666 \%$ in the northwestern coastal zone of Egypt. Likewise, the urban expansion of 309\% that was experienced in the GPH watershed is considered significant. In contrast, Yuan et al. [52] found that only a $38 \%(<100 \%)$ change occurred in the Minnesota metropolitan area between 1985-2002. Hegazy and Kaloop [19] concluded that a less significant change (67\%) took place between 1984-2000 in Mansoura and Talkha cities in Egypt. In short, previous studies have demonstrated great variability, with a range of drivers influencing the extent of land-use change. This study places the estimated land-use change to urban area between the upper and lower estimates of previous studies.

Urban land is usually a relatively small proportion of total land cover in many catchments [47,53-55], which is consistent with the findings in this study. According to Allan [54], urban land exceeded only $5 \%$ of the catchment area in 29 river basins and $10 \%$ in only 10 of the 150 large basins studied. However, in this study area, urban area was greater than $10 \%$ by 2003 , and is likely to reach $20 \%$ in 2060 . However, even at low percentages, permeable surfaces in urban areas can have a disproportionate impact on flooding $[54,56]$, which means that a significant change in the extent of urban land in the 
GPH watershed is expected to cause dramatic changes in peak discharge. The findings in this study are also consistent with other studies indicating that agricultural land occupies the largest proportion of land area in various developed catchments, whereas urban land occupies a much smaller portion [54].

Studies of LULC changes in other watersheds have shown variable results. Built-up areas increased by $100 \%\left(13.64 \mathrm{~km}^{2}\right.$ year $\left.^{-1}\right)$ in the Upper Citarum Watershed, West Java Province in Indonesia between 1997-2005 [57], while the urban area in the Simly Watershed, Islamabad (Pakistan) increased by $80 \%\left(0.42 \mathrm{~km}^{2}\right.$ year $\left.^{-1}\right)$ between 1992-2012 [58]. However, a study in the Weihe River Basin of northwest China [59] detected that the urban area increased by only $16 \%\left(15.5 \mathrm{~km}^{2} / \mathrm{year}^{-1}\right.$. A study analysing the multi-annual changes in urban area in Shijiazhuang City found that urban area increased by $81.5 \%$ between 1987-2001 [60], where urban growth was referred to as 'fast expansion' because the urban area grew at a rate of about $5.6 \mathrm{~km}^{2} /$ year. In this study, it was found that the urban area increased at a rate of about $24 \mathrm{~km}^{2} /$ year between 1986-2003, suggesting that the GPH watershed experienced a higher rate of urbanisation than in these other cities, and can be described based on Xiao et al. [60] study as "fast expansion".

Identifying the driving forces of land-use change is valuable for enhancing the understanding of the nature, extent, and spatial pattern of urban expansion, and for delivering effective future land-use plans. Six (6) main categories of driving forces are frequently considered in studies: physical, socioeconomic, proximity, accessibility, neighbourhood, and policy factors [61-63]. Prior research on the study area has shown that socioeconomic factors (mainly population eruption) are the main driving force of land-use change $[13,37,64-66]$. The population growth that was experienced in the area-from about 700,000 in 1991 to about one million inhabitants in 2006 [37]—coincides with the rapid land consumption for urban expansion that was reported in this study. A local social survey in 1989 revealed that migrants accounted for $72 \%$ of the city's population, where $65 \%$ of the migrant population originated from rural areas [13]. This suggests that rural-urban migration contributed considerably to the expansion of the city, which could be due to the petroleum-related economic activities in the area.

Like Nigeria, population growth due to rural-urban migration is also the main cause of urban expansion in India and China [4]. While the drivers of urban expansion in Africa and Europe are both socioeconomic in nature, the rate of urban expansion is much slower in Europe, and is more related to gross domestic product (GDP) growth than population growth [4]. According to the United Nations (UN), the rural population in this area will continue to decline until 2050 [67] due to rural-urban migration. Since the rise in urban population is predicted to continue in the future, urban sprawl is likely to continue, and the accompanying increase in impermeable surfaces could have serious flood risk and planning implications.

Other socioeconomic drivers of land-use change in the area include the high cost of available land and the desire for a traditional water-based living [68]. In the past, migrants from riverine communities have resorted to squatting in informal shelters on waterfronts in the south of the city, creating areas of high population density, whereas migrants from upland areas tend to build informal settlements in the north of the city [68], which helps to explain the spatial distribution of urban land in the fringes of the city. Physical factors also affected the distribution of land-use change in the study area, since features such as rivers as well as excessively ponded areas and marshlands condition where people live in the city [14]. Nonetheless, low-income groups still live in such areas of high flood risk.

\subsection{What Is the Extent of Future Urban LULC Changes Due to the Implementation of the Plan by 2060?}

Regarding future changes, this study revealed that a significant change in the extent of the urban area by $80 \%$ is expected by 2060 , meaning that the new city's extent is projected to be twice the size of the city in 2003. This estimated change in size is comparable to trends in recent studies. For instance, one study projected that urban land is expected to increase by $27.5 \%$ between 2009-2030 [59]. Note that the built-up area is generally considered a parameter for quantifying urban sprawl, and can be quantified by measuring the changes in impervious surface $[3,23,69]$. Du et al. [20] predicted a 
rapid rise in impervious surface, from 23\% to 31\% between 2012-2018 with a corresponding impact on flooding. Similarly, the significant change in urban cover expected by 2060 in this study area implies that a future increase in urban surface is likely to have severe implications for flooding in the watershed.

The implications of the findings are profound, since urbanisation and loss of agricultural land were the dominant forces of land-use change in the GPH watershed. However, as in most regions, urbanisation in the study area was the main driving force in the past, and is likely to continue in the future, which implies that flood risk could increase dramatically due to likely drastic changes in the future. Even relatively small changes in the proportion of urban area can cause dramatic flooding effects $[20,56]$. If the catchment increases its percentage of impervious surface from $0-60 \%$ of its area due to urban growth, flow could increase two to five times of its pre-urbanisation state [70].

In 2012, Port Harcourt and other cities in the Niger River system suffered the effects of a disastrous flood event attributed to intense precipitation and developments upstream (GFDRR, 2013). The impact of the floods was reportedly very severe in Port Harcourt, leaving 363 people dead, 5851 injured, 3,891,314 others affected, and 3,871,530 displaced. Given the projected growth in urban area, urbanisation could increase the risk of flood in future if the development plan is poorly implemented.

Besides the flood risk implications, the planned expansion if poorly implemented could continue to significantly alter the natural landscape and disturb ecosystems as well as incur environmental, economic, and social costs [71-73]. For example, the rapid expansion of the city could also increase air pollution, traffic injury, and ecosystem services change. Moreover, the rapid land consumption may have other serious consequences, such as the loss of livelihoods due to a reduction of arable land, loss of biodiversity and critical habitats, and farmland displacement.

In addition to other residual driving forces such as population, land-use policy and planning could become the main driving factors of land-use change in the future due to the implementation of the master plan and associated land zoning. Although these could have positive impacts such as the provision of basic infrastructure and services, the construction of formal settlements, and the reduction of slums in some areas, this study argues that the proposed plan could amplify flood risk if poorly implemented. Moreover, urban expansion in the future could have negative consequences on environmental sustainability and quality of life if the policy is only applied in preferred areas.

\subsection{What Was the Nature of Historical LULC Changes?}

Regarding the nature of change, the data in this study revealed that three quarters (about $75 \%$ ) of the watershed persisted, while as much as $25 \%$ of the watershed transitioned from one land-use category to another between 1986-2003 (Table 8). Unlike other LULC categories, this study found that the transition to urban land cover was the most dynamic in terms of gross gain and net change, which are the most important measures of urban expansion [33]. Moreover, urban area exhibited the largest gross gain (about $9 \%$ of the watershed) and the smallest gross loss, leading to a high net change of around $8.6 \%$. Indeed, the most prominent transition was historically the conversion of agricultural land to urban land (Table 5), with $93.3 \%$ of all conversions to urban land resulting from agricultural land.

Beyond knowledge of the extent of change and land-use transitions, this study has extended knowledge of the watershed by providing new insights into the process of change that occurred historically between 1986-2003, demonstrating that urban transition was dominated by net changes (Tables 8-10). This implies that the transition from agricultural land to urban land experienced an actual change in extent rather than just a change in location (swap change).

It is expected that changes in the percentage of impermeable surfaces due to urbanisation would compound flood risk more than changes in a location. On the other hand, the prominent non-urban transitions such as agricultural land and forestland transitions were predominantly of swap type changes rather than net change, indicating that a considerable amount of agricultural and forest lands experienced relocation. While the effect is likely to be less dramatic than change to urban land use, the 
relocation of forests could still have some flood implications because changes in surface roughness can have a significant impact on small local sub-basins [74].

The phenomena observed in the GPH watershed were comparable to findings in other watersheds such as the Mara River Basin in East Africa. For example, Mwangi et al. [75] found that swap changes accounted for more than $50 \%$ of the overall LULC changes. In our study, swap changes accounted for over $60 \%$ of the total changes in the GPH watershed, suggesting that the GPH watershed is very dynamic in terms of land cover relocation, resulting from accelerated farming activities in the area and high afforestation. Therefore, this study supports the argument that reporting only net changes can underestimate the total land-use change in landscapes [36].

The study also revealed that the prominent non-urban shifts were from forest to agricultural land (approximately $321.0 \mathrm{~km}^{2}$ ) and from agricultural land to forest (about $229.5 \mathrm{~km}^{2}$ ) between 1986-2003 (Table 8), which was not expected. These findings relate to the whole watershed and in part corroborate previous research findings, which covered a smaller part of the landscape. Although the impacts of such conversions vary at the watershed scale, the vulnerability to flooding may increase locally due to changes in soil infiltration capacity and increased surface runoff. Deforestation can also have severe implications for flooding because of reduced interception losses; however, the precise effect in large watersheds varies for different watersheds [76]. From the analysis, $73 \mathrm{~km}^{2}$ of the forest was eventually lost between 1986-2003. However, the large fraction of forest land-use change was a swap type of change $\left(568 \mathrm{~km}^{2}\right)$ rather than a change in a quantity. This observation implies forest disturbance, which can accelerate the rate that precipitation becomes streamflow depending on the catchment and storm size.

\subsection{What Are the Dominant Forces and Tendencies of Land-Use Change?}

This study has furthered the understanding of the landscape dynamics (in terms of the landscapes tendency to change) by revealing that urban land exhibited the highest gain-to-persistence ratio of 4.6 (far greater than one), as shown in Table 11. This means that urban land exhibited the greatest tendency to expand, while in contrast, agricultural land exhibited a low tendency to expand. Meanwhile, the observed changes in forest area was dynamic, showing a tendency to both expand and contract over time. Therefore, based on the findings of the extent of change, trend of change, process of change, and tendency of change presented, this study emphasises that urbanisation has been the most dominant force of land-use change in the watershed, which is likely to continue up to 2060.

\subsection{Does the Application of the Multisource Data Affect Result Accuracy?}

No change detection method is perfect, and similar to other studies, the results are presented with the caveat that uncertainties could arise due to possible errors from digitisation, input data quality, and the assumptions made. In particular, the use of multi-sourced data could have increased uncertainty in the results of this study due to the overclassification of some categories, as suggested by the mangrove class in the 1995 map (Figure 4). Nevertheless, uncertainties as a result of urban land-cover change seemed insignificant. Results were generally deemed dependable because of the reliability of the classification method applied, the similarity in the trend of changes in the two classified TM maps used in this study, the similarity in the trend of changes of the classified maps in this study when compared to other studies of the area, the author's knowledge of the landscape, and the accuracy of assessment. This study was used to demonstrate that multi-sourced data could increase uncertainty in change detection analysis.

\section{Conclusions}

The Greater Port Harcourt watershed has experienced substantial changes in land use/land cover over the last few decades. The dominant force of land-use change in the watershed has been urbanisation. Prominent transitions include shifts from agricultural land to urban land, as well as agricultural land to forest land. The conversion to urban land was the most dominant land-use change 
in the watershed (about $415 \mathrm{~km}^{2}$ ), and about $93 \%$ of this conversion was chiefly at the expense of agricultural land. The transition to urban land mainly experienced a net change process, which implies a change in actual quantity. The loss of agricultural land was another dominant force of land-use change; however, agricultural land mainly exhibited a swap process of change, i.e., mainly relocation. Reporting the net changes alone fails to capture the swap component, since it underestimates the total change, and could therefore be misleading. Beyond land-use expansion and transitions, this study provides new insights into the nature or process of change in the watershed that have not been previously reported. Generally, swap change explains up to $64 \%$ of the overall changes in this watershed. This means that more changes may have occurred in the watershed than those captured in previous studies.

The important lesson learnt from this study is that the scale of an urban landscape studied can have an impact on the examined extent of change compared to other similar studies. While the use of multi-source data could introduce error and increase uncertainty in estimating changes for data-sparse regions, the important messages are that: (1) urban expansion was rapid; (2) the expansion could rapidly increase by 2060 due to the GPH development; (3) the rapid urban expansion occurred mainly at the expense of agricultural land; and (4) changes to urban area were predominantly net rather than swap-type changes.

Author Contributions: Conceptualization, N.G.D.-J. and M.J.M.; Methodology, N.G.D.-J.; Writing-Original Draft Preparation, N.G.D.-J. and M.J.M.; Writing—Review \& Editing, N.G.D.-J., and A.P.C.; Supervision, M.J.M.

Funding: This research received no external funding.

Acknowledgments: The authors' wishes to acknowledge the assistance of Rivers State Sustainable Development Agency for funding PhD students in the state and the Greater Port-Harcourt Development Authority for releasing some data used in analysis in this research. We also wish to thank other contributors for their effort, time and generosity of spirit, especially to Meriwether Wilson for her supervisory role and Owen McDonald for his technical assistance.

Conflicts of Interest: The authors declare no conflicts of interest.

\section{References}

1. Wheater, H.; Evans, E. Land use, water management and future flood risk. Land Use Policy 2009, 26 (Suppl. 1), S251-S264. [CrossRef]

2. Jha, A.K.; Bloch, R.; Lamond, J. Cities and Flooding: A Guide to Integrated Urban Flood Risk Management for the 21st Century; World Bank Publications: Washington, DC, USA, 2012.

3. Miller, J.D.; Kim, H.; Kjeldsen, T.R.; Packman, J.; Grebby, S.; Dearden, R. Assessing the impact of urbanization on storm runoff in a peri-urban catchment using historical change in impervious cover. J. Hydrol. 2014, 515, 59-70. [CrossRef]

4. Seto, K.C.; Fragkias, M.; Güneralp, B.; Reilly, M.K. A meta-analysis of global urban land expansion. PLoS ONE 2011, 6, e23777. [CrossRef] [PubMed]

5. Savini, J.; Kammerer, J.C. Urban Growth and the Water Regimen; US Govt. Print. Off.: Arlington, VA, USA, 1961.

6. Davis, K. The urbanization of the human population. Sci. Am. 1965, 213, 40-53. [CrossRef]

7. UN. World Urbanization Prospects 2014: Highlights; United Nations Publications: New York, NY, USA, 2014.

8. UNFCCC. Climate Change: Impacts, Vulnerabilities and Adaptation in Developing Countries; Climate Change Secretariat (UNFCCC): Bonn, Germany, 2007.

9. Osti, R.; Tanaka, S.; Tokioka, T. Flood hazard mapping in developing countries: Problems and prospects. Disaster Prev. Manag. Int. J. 2008, 17, 104-113. [CrossRef]

10. Li, W.; Xie, Y.; Hao, F. Applying an improved rapid impact assessment matrix method to strategic environmental assessment of urban planning in China. Environ. Impact Assess. Rev. 2014, 46, 13-24. [CrossRef]

11. Abam, T.K.S. Regional Hydrological Research Perspectives in the Niger Delta. Hydrol. Sci. J. 2001, 46, 13-25. [CrossRef]

12. Wolpe, H. Urban politics in Nigeria: A study of Port Harcourt; University of California Press: Berkeley, CA, USA, 1974. 
13. Izeogu, C.V. Urban development and the environment in Port Harcourt. Environ. Urban. 1989, 1, 59-68. [CrossRef]

14. Verml. Greater Port-Harcourt City Phase 1A Development Environmental Impact Assessment; Greater Port-Harcourt City Development Authourity: Port Harcourt, Nigeria, 2009.

15. Theis, M.; Lloyd-Jones, T.; Adenekan, S.; Gusah, S.; Moor, M.; Mulyawan, B.; Gusah, D. Port Harcourt Waterfront Urban Regeneration: Scoping Study. Project Report; 1905632061; MLC Press, University of Westminister: London, UK, 2009.

16. Cookey-Gam, A. An Overview of the Greater Port Harcourt City Master Plan and Opportunities in Building a World Class City over the Next 20 Years; Greater Portharcourt Development Authority: Portharcourt, Nigeria, 2010.

17. Zanganeh Shahraki, S.; Sauri, D.; Serra, P.; Modugno, S.; Seifolddini, F.; Pourahmad, A. Urban sprawl pattern and land-use change detection in Yazd, Iran. Habitat Int. 2011, 35, 521-528. [CrossRef]

18. Tripathi, R.; Sengupta, S.K.; Patra, A.; Chang, H.; Jung, I.W. Climate change, urban development, and community perception of an extreme flood: A case study of Vernonia, Oregon, USA. Appl. Geogr. 2014, 46, 137-146. [CrossRef]

19. Hegazy, I.R.; Kaloop, M.R. Monitoring urban growth and land use change detection with GIS and remote sensing techniques in Daqahlia governorate Egypt. Int. J. Sustain. Built Environ. 2015, 4, 117-124. [CrossRef]

20. Du, J.; Qian, L.; Rui, H.; Zuo, T.; Zheng, D.; Xu, Y.; Xu, C.Y. Assessing the effects of urbanization on annual runoff and flood events using an integrated hydrological modeling system for Qinhuai River basin, China. J. Hydrol. 2012, 464-465, 127-139. [CrossRef]

21. Chen, Y.; Zhou, H.; Zhang, H.; Du, G.; Zhou, J. Urban flood risk warning under rapid urbanization. Environ. Res. 2015, 139, 3-10. [CrossRef] [PubMed]

22. Ali, M.; Khan, S.J.; Aslam, I.; Khan, Z. Simulation of the impacts of land-use change on surface runoff of Lai Nullah Basin in Islamabad, Pakistan. Landsc. Urban Plan. 2011, 102, 271-279. [CrossRef]

23. Suriya, S.; Mudgal, B.V. Impact of urbanization on flooding: The Thirusoolam sub watershed-A case study. J. Hydrol. 2012, 412-413, 210-219. [CrossRef]

24. Knebl, M.R.; Yang, Z.L.; Hutchison, K.; Maidment, D.R. Regional scale flood modeling using NEXRAD rainfall, GIS, and HEC-HMS/RAS: A case study for the San Antonio River Basin Summer 2002 storm event. J. Environ. Manag. 2005, 75, 325-336. [CrossRef] [PubMed]

25. McColl, C.; Aggett, G. Land-use forecasting and hydrologic model integration for improved land-use decision support. J. Environ. Manag. 2007, 84, 494-512. [CrossRef] [PubMed]

26. Duan, M.; Zhang, J.; Liu, Z.; Aekakkararungroj, A. Use of remote sensing and GIS for flood hazard mapping in Chiang Mai Province, northern Thailand. In Proceedings of the International Conference on Geospatial Solutions for Emergency Management and the 50th Anniversary of the Chinese Academy of Surveying and Mapping, Beijing, China, 14-16 September 2009; pp. 14-16.

27. Yang, X.T.; Liu, H.; Gao, X. Land cover changed object detection in remote sensing data with medium spatial resolution. Int. J. Appl. Earth Obs. Geoinform. 2015, 38, 129-137. [CrossRef]

28. Oni, S.K.; Futter, M.N.; Buttle, J.; Dillon, P.J. Hydrological footprints of urban developments in the Lake Simcoe watershed, Canada: A combined paired-catchment and change detection modelling approach. Hydrol. Process. 2015, 29, 1829-1843. [CrossRef]

29. Deng, J.S.; Wang, K.; Hong, Y.; Qi, J.G. Spatio-temporal dynamics and evolution of land use change and landscape pattern in response to rapid urbanization. Landsc. Urban Plan. 2009, 92, 187-198. [CrossRef]

30. Al Kuwari, N.Y.; Kaiser, M.F. Impact of North Gas Field development on landuse/landcover changes at Al Khore, North Qatar, using remote sensing and GIS. Appl. Geogr. 2011, 31, 1144-1153. [CrossRef]

31. Abd El-Kawy, O.R.; Rød, J.K.; Ismail, H.A.; Suliman, A.S. Land use and land cover change detection in the western Nile delta of Egypt using remote sensing data. Appl. Geogr. 2011, 31, 483-494. [CrossRef]

32. Lunetta, R.S.; Knight, J.F.; Ediriwickrema, J.; Lyon, J.G.; Worthy, L.D. Land-cover change detection using multi-temporal MODIS NDVI data. Remote Sens. Environ. 2006, 105, 142-154. [CrossRef]

33. Lu, D.; Mausel, P.; Brondízio, E.; Moran, E. Change detection techniques. Int. J. Remote Sens. 2004, 25, 2365-2401. [CrossRef]

34. Singh, A. Review Article Digital change detection techniques using remotely-sensed data. Int. J. Remote Sens. 1989, 10, 989-1003. [CrossRef] 
35. Peiman, R. Pre-classification and post-classification change-detection techniques to monitor land-cover and land-use change using multi-temporal Landsat imagery: A case study on Pisa Province in Italy. Int. J. Remote Sens. 2011, 32, 4365-4381. [CrossRef]

36. Pontius, R.G.; Shusas, E.; McEachern, M. Detecting important categorical land changes while accounting for persistence. Agric. Ecosyst. Environ. 2004, 101, 251-268. [CrossRef]

37. Mmom, P.C.; Fred-Nwagwu, F.W. Analysis of Landuse and Landcover Change around the City of Port Harcourt, Nigeria. Glob. Adv. Res. J. 2013, 2, 76-86.

38. Ikechukwu, E.E. The Socio-Economic Impact of the Greater Port Harcourt Development Project on the Residents of the Affected Areas. Open J. Soc. Sci. 2015, 3, 82-93. [CrossRef]

39. Demographia. Demographia World Urban Areas; Demographia: Paris, France, 2017.

40. NDDC. Niger Delta Regional Development Master Plan; Niger Delta Development Commission: Port Harcourt, Nigeria, 2006.

41. Omole, F.K.; Akinbamijo, O.B. Land development and planning laws in Nigeria: The historical account. J. Law Policy Glob. 2012, 8, 25.

42. Lamond, J.; Awuah, K.B.; Lewis, E.; Bloch, R.; Falade, J.B. Urban Land, Planning and Governance Systems in Nigeria; Project Report; ICF International: London, UK, 2015.

43. Aribigbola, A. Imroving urban land use planning and management in Nigeria: The case of Akure. Cercet. Pr. Si Teor. In Manag. Urban 2008, 3, 1-14.

44. Ede, P.N.; Owei, O.B.; Akarolo, C.I. Does the Greater Port Harcourt Master Plan 2008 meet Aspirations for Liveable City. In Proceedings of the ISOCARP Congress 2011 Liveable Cities-Urbanising World, Meeting the Challenge, Wuhan, China, 25-28 October 2011; p. 12.

45. Nagi, R. Classifying Landsat Image Services to Make a Land Cover Map. Available online: http:/ / blogs.esri. com/esri/arcgis/2011/05/28/classifying-landsat-image-services-to-make-a-land-cover-map/ (accessed on 6 September 2015).

46. Richards, J.A.; Richards, J. Remote Sensing Digital Image Analysis; Springer: Berlin/Heidelberg, Germany, 1999; Volume 3.

47. Kafi, K.; Shafri, H.; Shariff, A. An analysis of LULC change detection using remotely sensed data; A Case study of Bauchi City. In Proceedings of the IOP Conference Series: Earth and Environmental Science, Beijing, China, 22-26 April 2013; p. 012056.

48. Enaruvbe, G.O.; Ige-Olumide, O. Geospatial analysis of land-use change processes in a densely populated coastal city: The case of Port Harcourt, south-east Nigeria. Geocarto Int. 2014, 30, 441-456. [CrossRef]

49. Viera, A.J.; Garrett, J.M. Understanding interobserver agreement: The kappa statistic. Fam. Med. 2005, 37, 360-363. [PubMed]

50. Howarth, P.J.; Wickware, G.M. Procedures for change detection using Landsat digital data. Int. J. Remote Sens. 1981, 2, 277-291. [CrossRef]

51. Shalaby, A.; Tateishi, R. Remote sensing and GIS for mapping and monitoring land cover and land-use changes in the Northwestern coastal zone of Egypt. Appl. Geogr. 2007, 27, 28-41. [CrossRef]

52. Yuan, F.; Sawaya, K.E.; Loeffelholz, B.C.; Bauer, M.E. Land cover classification and change analysis of the Twin Cities (Minnesota) Metropolitan Area by multitemporal Landsat remote sensing. Remote Sens. Environ. 2005, 98, 317-328. [CrossRef]

53. Chavez, P.S.; MacKinnon, D.J. Automatic detection of vegetation changes in the southwestern United States using remotely sensed images. Photogramm. Eng. Remote Sens. 1994, 60, 571-582.

54. Allan, J.D. Landscapes and riverscapes: The influence of land use on stream ecosystems. Annu. Rev. Ecol. Evol. Syst. 2004, 35, 257-284. [CrossRef]

55. Manandhar, R.; Odeh, I.O.A.; Pontius, R.G., Jr. Analysis of twenty years of categorical land transitions in the Lower Hunter of New South Wales, Australia. Agric. Ecosyst. Environ. 2010, 135, 336-346. [CrossRef]

56. Leopold, L. Hydrology for urban planning. In US Geological Survey; Washington, DC, USA, 1968; Available online: http:/ / eps.berkeley.edu/people/lunaleopold/ (accessed on 19 November 2018).

57. Agaton, M.; Setiawan, Y.; Effendi, H. Land Use/Land Cover Change Detection in an Urban Watershed: A Case Study of Upper Citarum Watershed, West Java Province, Indonesia. Procedia Environ. Sci. 2016, 33, 654-660. [CrossRef] 
58. Butt, A.; Shabbir, R.; Ahmad, S.S.; Aziz, N. Land use change mapping and analysis using Remote Sensing and GIS: A case study of Simly watershed, Islamabad, Pakistan. Egypt. J. Remote Sens. Space Sci. 2015, 18, 251-259. [CrossRef]

59. He, C.; Zhao, Y.; Huang, Q.; Zhang, Q.; Zhang, D. Alternative future analysis for assessing the potential impact of climate change on urban landscape dynamics. Sci. Total Environ. 2015, 532, 48-60. [CrossRef] [PubMed]

60. Xiao, J.; Shen, Y.; Ge, J.; Tateishi, R.; Tang, C.; Liang, Y.; Huang, Z. Evaluating urban expansion and land use change in Shijiazhuang, China, by using GIS and remote sensing. Landsc. Urban Plan. 2006, 75, 69-80. [CrossRef]

61. Quan, B.; Chen, J.-F.; Qiu, H.-L.; Römkens, M.J.M.; Yang, X.-Q.; Jiang, S.-F.; Li, B.-C. Spatial-temporal pattern and driving forces of land use changes in Xiamen. Pedosphere 2006, 16, 477-488. [CrossRef]

62. Hersperger, A.; Bürgi, M. Driving forces of landscape change in the urbanizing Limmat valley, Switzerland. In Modelling Land-Use Change; Springer: Dordrecht, The Netherlands, 2007; pp. 45-60.

63. Li, G.; Sun, S.; Fang, C. The varying driving forces of urban expansion in China: Insights from a spatial-temporal analysis. Landsc. Urban Plan. 2018, 174, 63-77. [CrossRef]

64. Akukwe, T.I.; Ogbodo, C. Spatial Analysis of Vulnerability to Flooding in Port Harcourt Metropolis, Nigeria. SAGE Open 2015, 5. [CrossRef]

65. Owei, O.B.; Obinna, V.C.; Ede, P.N. The Challenges of Sustainable Land Use Planning in Nigerian Cities. The Case of Port Harcourt. In Proceedings of the ISOCARP Congress, Nairobi, Kenya, 19-23 September 2010.

66. Wizor, C.H. Residential Development Dynamics in Port Harcourt Metropolis: Implication for Efficient Urban Planning. J. Environ. Earth Sci. 2014, 4, 78-85.

67. UNDESA. World Urbanization Prospects: The 2014 Revision. United Nations, Department of Economic and Social Affairs; Population Division: New York, NY, USA, 2015.

68. Obafemi, A.A.; Odubo, T.V. Waterfronts Redevelopments in Port Harcourt Metropolis: Issues and Socio-Economic Implications for Urban Environmental Management. Int. J. Eng. Sci. 2013, 2, 1-14.

69. Sudhira, H.S.; Ramachandra, T.V.; Jagadish, K.S. Urban sprawl: Metrics, dynamics and modelling using GIS. Int. J. Appl. Earth Obs. Geoinform. 2004, 5, 29-39. [CrossRef]

70. Abbas, H.B.; Routray, J.K. Assessing factors affecting flood-induced public health risks in Kassala State of Sudan. Oper. Res. Health Care 2014, 3, 215-225. [CrossRef]

71. Wu, K.-Y.; Ye, X.-Y.; Qi, Z.-F.; Zhang, H. Impacts of land use/land cover change and socioeconomic development on regional ecosystem services: The case of fast-growing Hangzhou metropolitan area, China. Cities 2013, 31, 276-284. [CrossRef]

72. Liang, J.; Zhong, M.; Zeng, G.; Chen, G.; Hua, S.; Li, X.; Yuan, Y.; Wu, H.; Gao, X. Risk management for optimal land use planning integrating ecosystem services values: A case study in Changsha, Middle China. Sci. Total Environ. 2017, 579, 1675-1682. [CrossRef] [PubMed]

73. Cobbinah, P.B.; Erdiaw-Kwasie, M.O.; Amoateng, P. Africa's urbanisation: Implications for sustainable development. Cities 2015, 47, 62-72. [CrossRef]

74. Ozdemir, H.; Sampson, C.; de Almeida, G.A.; Bates, P. Evaluating scale and roughness effects in urban flood modelling using terrestrial LIDAR data. Hydrol. Earth Syst. Sci. 2013, 10, 5903-5942. [CrossRef]

75. Mwangi, H.M.; Julich, S.; Patil, S.D.; McDonald, M.A.; Feger, K.H. Modelling the impact of agroforestry on hydrology of Mara River Basin in East Africa. Hydrol. Process. 2016, 30, 3139-3155. [CrossRef]

76. Bathurst, J.C.; Iroumé, A.; Cisneros, F.; Fallas, J.; Iturraspe, R.; Novillo, M.G.; Urciuolo, A.; de Bièvre, B.; Borges, V.G.; Coello, C.; et al. Forest impact on floods due to extreme rainfall and snowmelt in four Latin American environments 1: Field data analysis. J. Hydrol. 2011, 400, 281-291. [CrossRef]

(C) 2018 by the authors. Licensee MDPI, Basel, Switzerland. This article is an open access article distributed under the terms and conditions of the Creative Commons Attribution (CC BY) license (http:/ / creativecommons.org/licenses/by/4.0/). 